\title{
Pan-African Paleostresses and Reactivation of the Eburnean Basement Complex in Southeast Ghana (West Africa)
}

\author{
Mahaman Sani Tairou, ${ }^{1}$ Pascal Affaton, ${ }^{2}$ Solomon Anum, ${ }^{3}$ and Thomas Jules Fleury ${ }^{2}$ \\ ${ }^{1}$ Département de Géologie, Faculté des Sciences, Université de Lomé, BP 1515, Lomé, Togo \\ ${ }^{2}$ Aix-Marseille Université, CNRS, IRD, CEREGE UMR34, 13545 Aix en Provence Cedex 04, France \\ ${ }^{3}$ Geological Survey Department, Koforidua Eastern Region, P.O. Box 672, Koforidua, Ghana
}

Correspondence should be addressed to Mahaman Sani Tairou, msanitairou@yahoo.fr

Received 28 March 2012; Revised 18 May 2012; Accepted 25 May 2012

Academic Editor: Quan-Lin Hou

Copyright (C) 2012 Mahaman Sani Tairou et al. This is an open access article distributed under the Creative Commons Attribution License, which permits unrestricted use, distribution, and reproduction in any medium, provided the original work is properly cited.

This faulting tectonics analysis concerns the southernmost segment of the Dahomeyide Orogen and the West-African craton eastern margin in southeast Ghana. The analysis of strike-slip faults in the frontal units of the Dahomeyide Belt indicates that four distinct compressive events (NE-SW, ENE-WSW to E-W, ESE-WNW to SE-NW and SE-NW to SSE-NNW) originated the juxtaposition of the Pan-African Mobile Zone and the West-African craton. These paleostress systems define a clockwise rotation of the compressional axis during the structuring of the Dahomeyide Orogen (650-550 Ma). The SE-NW and SSE-NNW to N-S compressional axes in the cratonic domain and its cover (Volta Basin) suggest that the reactivation of the eastern edge of the West African craton is coeval with the last stages of the Pan-African tectogenesis in southeast Ghana. An extensional episode expressed as late normal faulting is also recorded in this study. This E-W to SE-NW extension, which is particular to the southernmost part of the Dahomeyide Belt, appears to be post-Pan-African. This extension probably contributed to the formation of a major Jurassic rifting zone that originated the Central Atlantic and the Benue Trough.

\section{Introduction}

Southeast Ghana is a geologically complex area (Figure 1). It includes three distinct structural domains [1-5] (1) the southeastern margin of the West african craton (WAC) consisting of Archean to Paleoproterozoic assemblages that underwent the Eburnean Orogeny $(2000 \pm 200 \mathrm{Ma}) ;(2)$ the Neoproterozoic Volta Basin represented by its lower and middle megasequences (Bombouaka and Oti Supergroups); (3) the frontal structural units of the Pan-African Dahomeyide Orogenic Belt $(600 \pm 50 \mathrm{Ma})$.

The sedimentary sequence in the Volta Basin rests unconformably on the Eburnean basement complex. This basement and its cover constitute the western "Stable Zone" of our study area (with rock assemblages that did not undergo the Pan-African thermotectonic events); the eastern "Mobile Zone" is represented by the frontal part of the Pan-African Dahomeyide Orogenic Belt (Figures 1 and 2). This Mobile Zone overthrusts the Volta Basin in the North and its Eburnean basement in the South. The Mobile Zone is described as a pile of west verging nappes involved in several folding phases $[1,6-10]$. This juxtaposition of distinct lithostructural assemblages was resulted from the Pan-African tectogenesis. However, the characteristics of this tectogenesis are not yet well known, particularly in southeast Ghana.

At the scale of satellite images or aerial photographs and outcrops, this Pan-African tectogenesis is strongly expressed as a dense network of polyphase lineaments and fractures. The analytical study of these fractures will lead to the following: (1) characterization of the Pan-African paleostresses in the southernmost Dahomeyide segment, and (2) identification of the Pan-African markers on the southeastern margin of the Eburnean basement complex and its cover represented by the Volta Basin (i.e., on the Stable Zone). Following the work done on the Pan-African fracturing in southwest Niger [11] and northern Togo [10, $12,13]$, the present tectonic analysis will lead to a better 


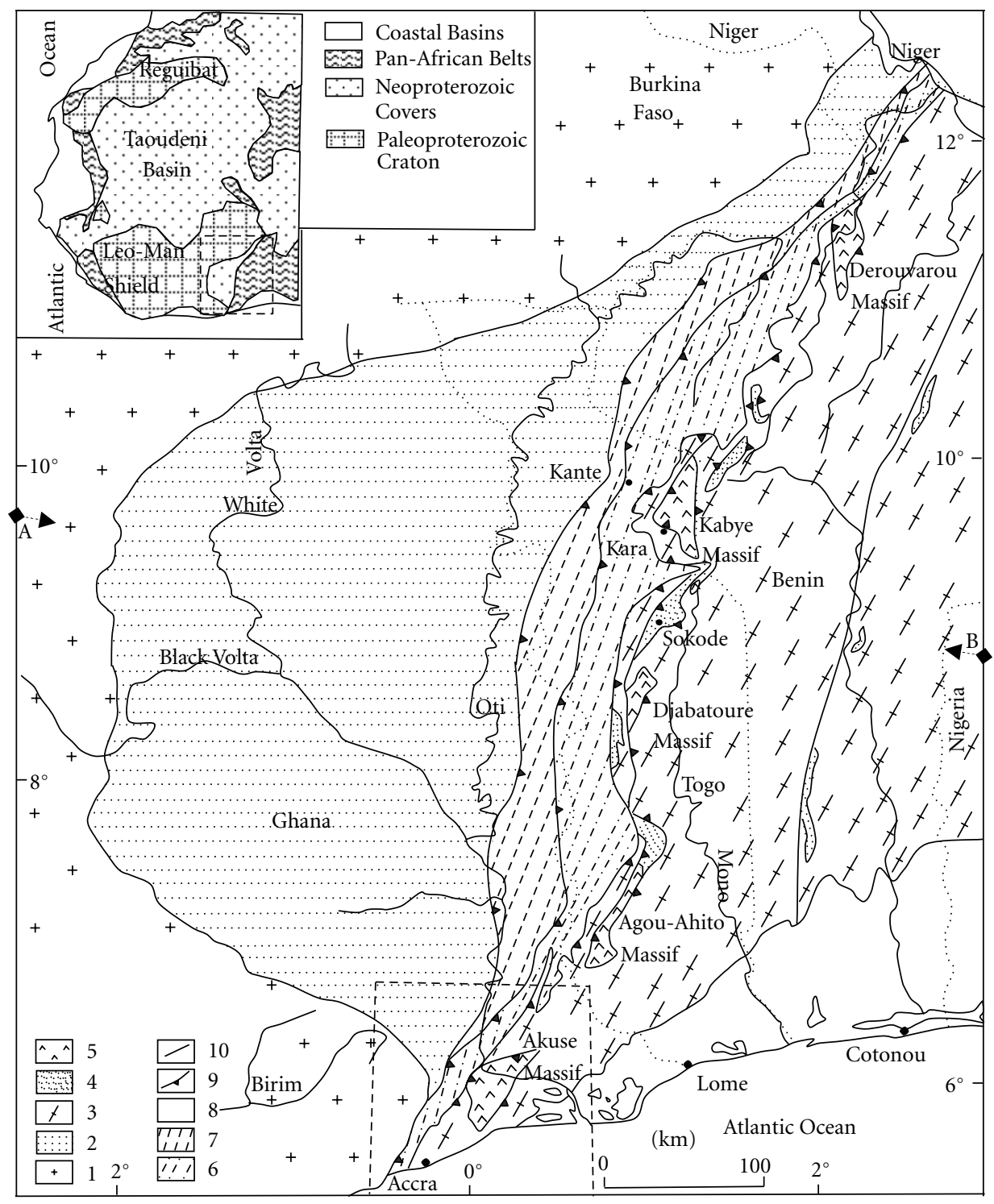

FIGURE 1: Schematic geological map with the "Stable Zone" (comprising the southeastern margin of the West african craton and its cover represented by the Volta Basin) and the Pan-African "Mobile Zone" (i.e., the frontal structural units of the Pan-African Dahomeyide belt): 1 = Eburnean basement complex (WAC); 2 = Neoproterozoic to Paleozoic cover (Volta Basin); $3=$ internal and external gneiss-migmatite units; 4 = kyanite bearing micaceous quartzites; 5 = basic and ultrabasic massifs of the suture zone; $6=$ Atacora or Akwapim structural unit; 7 = Buem structural unit; $8=$ Meso-Cenozoic cover of the Gulf of Guinea Basin; $9=$ thrust contact; $10=$ Kandi fault mylonitic zone; A-B = schematic section line (Figure 2).

Stable Zone

WNW

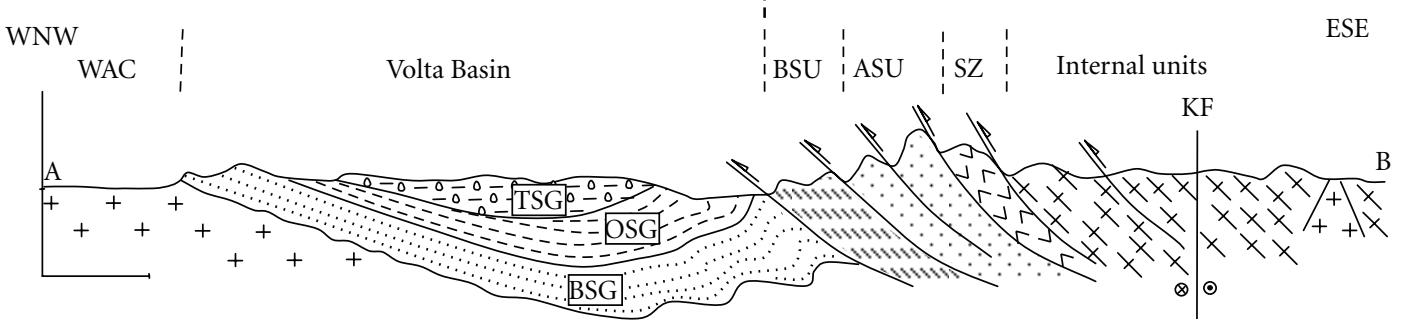

Figure 2: Schematic cross section (A-B, Figure 1) showing the relationships between the Stable Zone (i.e., the West african craton and the Volta Basin, with BSG = Bombouaka Supergroup, OSG = Oti Supergroup, TSG = Tamale Supergroup) and the Pan-African Mobile Zone (BSU = Buem structural unit; ASU = Atacora or Akwapim structural unit; SZ = suture zone; KF = Kandi fault). 
understanding of the Pan-African paleostress orientations in the Dahomeyide Orogenic Belt.

\section{Geological Setting}

In the geological framework of this tectonic study, it is important to distinguish two different lithostructural domains as follows: the West-African Craton and its cover (Volta Basin) as the "Stable Zone" and the Pan-African domain made up of the frontal part of the Pan-African Dahomeyide Orogenic Belt as the "Mobile Zone" (Figures 1 and 2).

2.1. The Stable Zone. The Stable Zone corresponds to the southeastern margin of the Guinea [14] or Leo-Man Shield and its Neoproterozoic cover represented by the Volta Basin $[1,5,9]$. In southeast Ghana, the Stable Zone is mainly composed of Archean to Paleoproterozoic rocks involved in the Eburnean thermotectonic events and stabilized at the end of this orogeny $(2000 \pm 200 \mathrm{Ma})$. The Eburnean orogeny was not strongly rejuvenated during the Pan-African thermotectonic events $(600 \pm 50 \mathrm{Ma})$.

In Ghana, the West-African Craton is roughly equivalent of a gneiss-migmatite basement complex that includes multiple generations of granitic bodies. This complex contains supracrustal belts represented by volcanic, metavolcanosedimentary or mainly metasedimentary formations defined as the Birimian and Tarkwaian units or groups [15]. In this basement complex, the first granite generations are orthognessic and more or less migmatitic. These rocks are of granodiorite origin and Eburnean age (2200-2000 Ma; $[16,17])$. Considering the recently recorded $2600 \mathrm{Ma}$ ages $[4,14,18]$, it is possible that these ancient granites are of Archean origin. The second generations are nonfoliated and crosscut young granites, sometimes very potassic in composition [2].

The supracrustal belts include a lower assemblage, the Birimian unit, and an upper assemblage, the Tarkwaian unit $[2,14,15]$. The lower assemblage includes the Lower Birimian unit, made up of metapelites associated with metamorphic rocks of various origins (greywackes, sandstones, arkoses, volcanic tuffs, siltites, volcanites, and pyroclastites); the Upper Birimian Unit is composed mainly of magmatic rocks (basic to intermediate lavas associated with pyroclastites, agglomerates, volcanic tuffs, and arkosic intercalations). According to Dampare et al. [19], the geochemical characteristics of the basaltic to andesitic metavolcanites indicate emplacement of these Birimian formations in an insular back-arc environment. The Birimian formations record three phases of deformation which, respectively, reflect the development of a NNE-SSW trending foliation, tight synforms and antiforms with NNE-SSW axes, and folding-induced cleavages crosscutting the earlier structures [14].

As regards the Tarkwaian formation, it is described essentially as a detrital assemblage unconformably on the Birimian unit [20]. It consists of polymictic conglomerates, gold-bearing conglomeratic quartzites, phyllites, and feldspathic sandstones. Very moderately folded and fractured by cleavages, it corresponds to an early molasse of the Eburnean orogeny and exhibits a weak overprint of late Eburnean tectonic structures [15].

The sedimentary sequence of the Volta Basin lies unconformably on the southeastern margin of the West-African Craton (Figure 2). This basin appears as a semibasin (i.e., a half-basin), truncated to the East by the thrust front of the Dahomeyide Orogenic Belt $[1,9,21]$. Three megasequences are recognized. The lower megasequence or Bombouaka Supergroup (1000-600 Ma), represented in the boundary massifs, is made up of two sandy sequences with a mainly clayey-silty sequence sandwiched in between [1]. The middle megasequence or Oti Supergroup lies, with a pro-parte glacial unconformity, on the lower supergroup or directly on the Eburnean basement. It begins with a glaciogenic deposit (tillite or diamictite) that is overlain by carbonate and silexitic formations. The assemblage of these three marker deposits (i.e., tillite, carbonate, silexite) is called the "Triad" and underlies a thick Vendian formation $[4,22,23]$. The Vendian formation is predominantly clayey and silty, with little intercalations of carbonates, silexites, sandstones, and tholeiitic volcanites [24]. The upper megasequence or Tamale Supergroup, with a possible lower Palaeozoic age, consists of conglomeratic formations with glaciogenic deposit. The Tamale Supergroup is a molasse derived from the uplift and consecutive rapid erosion of the adjacent Dahomeyide Orogeny [7, 25].

Structurally, the lower and middle megasequences show significant eastward thickening in the Volta Basin where they are folded and partially incorporated into the frontal units of the Pan-African Dahomeyide Orogenic Belt [8-10, 25]. According to Affaton [7], the associated structural and geophysical characteristics indicate a composite geodynamic evolution. Thus, the sedimentary sequence in the Volta Basin must be considered as the result of superposition of a passive margin type lower basin, corresponding to the Bombouaka and Oti Supergroups, and a foreland basin represented by the molassic formations of the Tamale Supergroup.

\subsection{The Pan-African Mobile Zone. The Pan-African} Dahomeyide Belt is located on the southeastern margin of the West-African Craton (Figures 1 and 2). It comprises different lithostructural units in the West (external structural units) or in the East (internal structural units), in relationship with the granulitic and eclogitic massifs representing the suture zone $[1,10]$. The external structural units are composed of sediments and metasediments, representing the lateral equivalents of the lower and middle megasequences of the Volta Basin $[7,9,26]$, and/or gneissic nappes corresponding to the Eburnean rocks that were highly reworked during the Pan-African orogeny $[1,18,27-29]$.

The Buem structural unit corresponds to the outermost structural unit of the Dahomeyide Belt and has been directly overthrusted onto the Volta Basin or the Eburnean basement complex (Figures 1 and 2). It consists of sedimentary or weakly metamorphosed sedimentary rocks (shales, quartzitic sandstones, hematitic rocks, mixtites, and sericite-schists) associated with volcanites and serpentinized peridotites 
$[24,26]$. Its eastern part is characterized by a typical and strong imprint of cataclasis expressed as a dense tangle of quartz veinlets $[7,10]$. The Atacora or Akwapim structural unit is overthrusted onto the Buem and described as a thick pile of nappes, essentially schistose in the West and quartzitic in the East $[7,8,10]$. It tectonically underlies the external nappes of the reworked basement complex (the Kara-Niamtougou or Mô Orthogneissic units, the SokodéKéméni unit, the plutono-metamorphic Amlamé-Kpalimé and/or Ho unit) or the eclogitic/granulitic nappes of the suture zone [1, 29-31]. The suture zone is composed of highly metamorphosed rocks, showing a high gravitational gradient and strong crustal thickening [32-34]. The basic to ultrabasic massifs of this suture zone (Dérouvarou in northwest Benin; Kabye, Kpaza, Djabatouré-Anié, AgouAhito in Togo; and Akuse or Shai in southeast Ghana) are composed of granulites, locally eclogites, and carbonatites, associated with their retrograded equivalents, serpentinites, talcschists, and some metasedimentary rocks [1, 35-38].

The internal structural units are located to the East of the suture zone massifs, exposed as the western margin of the Benino-Nigerian metacraton [39]. They are made up of nappes of various gneisso-migmatitic complexes associated with quartzitic and minor amount of carbonated metasediments, intruded progressively by the Pan-African granites from the West $[1,40]$. The majority of these rocks is considered as an Eburnean complex widely reworked during the Pan-African thermotectonic events (650-550 Ma; [18]).

Such a lithostructural assemblages in the Pan-African Dahomeyide Belt indicates a collision belt and defines an eastward increasing metamorphic gradient $[1,10]$. The PanAfrican tectogenesis is also characterized by progressive eastward superposition of five-phase deformation, considered as $\mathrm{Dn}, \mathrm{Dn}+1, \mathrm{Dn}+2, \mathrm{Dn}+3$, and $\mathrm{Dn}+4[1,13]$. The Dn phase is coeval with the granularization resulted from the collision between the eastern margin of the West-African Craton and the Benino-Nigerian metacraton [41]. The tangential or nappe stacking phase ( $\mathrm{Dn}+1$ phase) corresponds to the formation of the main or regional foliation which is later involved in three postnappe $(\mathrm{Dn}+2$ to $\mathrm{Dn}+4)$ folding phases associated with the final development stages of the PanAfrican Dahomeyide Orogeny.

\section{Lineament Analysis}

The satellite image of the study area (Figure 3 ) clearly distinguishes two juxtaposed morphostructural domains (Figure 4(a)). A drastic contrast is revealed between the eastern Pan-African Mobile Zone and the western Stable Zone. The NNE-SSW Eburnean structural trends are well expressed within the Eburnean basement complex of this Stable Zone. On the contrary, the front of the Dahomeyide Belt clearly appears as a pile of west- or northwest-verging nappes. The regional submeridian foliation $(\mathrm{Sn}+1)$, is materialized by quartzitic bars, trending NE-SW. This foliation is refolded and cut by oblique kilometric lineaments which also follow NE-SW to ESE-WNW trends (Figure 4(c)). Within the craton and its cover (i.e., the Stable Zone), the network is much more tangled. Indeed, the photofacies of the Eburnean basement complex and the Volta Basin Supergroups display lineaments trending differently in the SE-NW to SSWNNE, NE-SW, and ESE-WNW directions (Figure 4(b)). In summary, the fracture networks of the Stable Zone and the Pan-African Mobile Zone are not superposable, even though their NE-SW and ENE-WSW lineaments seem comparable.

The relative complexity of the lineament network in the Stable Zone is interpreted to be due to the coexistence of Eburnean and Pan-African fractures. Such an hypothesis leads to an inference that, in response to the Pan-African tectogenesis, the Eburnean cratonic basement and its cover records Pan-African fractures and that the Eburnean fractures were reactivated.

The rectilinear character of all the lineaments observed in the study area indicates the presence of subvertical fracture planes. They are thus distinguishable from the thrust contacts that separate the nappes in the frontal part of the Dahomeyide Orogeny. Finally, the offset of quartzitic bands leads to consider some lineaments as true sinistral or dextral strike-slip faults (Figure 3).

\section{Tectonic Analysis}

4.1. Method. About 800 orientation measurements of striated planes were collected at fourteen faulted sites developing in different geological units in southeast Ghana (Figure 5). The studied outcrops are found in roadside sections or industrial quarries in competent rocks (granites, quartzites, micaceous quartzites, gneiss, dolomitic carbonates, and granulites ) displaying one or several fracturing episodes. The abundance of striated planes has allowed considering only those with true and the best criteria indicating movement [42]. The majority of microfractures considered in this paper are recognized as conjugated strike-slip planes. Moreover, the Akwapim metasediments display striated slickensides, showing reverse (Peduase sites) or normal motion. The latter type may be resulted from the later motion due to the fact that the pitch is structurally higher than the strike-slip one. At the sites, the chronology of the different families of fractures was established based on crosscutting and superposition of incompatible striations [43]. Thus, planes with mineral recrystallization (amphibole, biotite, quartz, sericite, and calcite) clearly appear to be anterior to the "dry" or simply striated planes.

A manual stereographic examination has allowed completing the characterization of the striations. Computer processing of the data was done by using Angelier's [44] method version 2000 for the calculation of stress tensor (R4DT, INDVIR; [45]). With regard to the quality of the results, only planes with good interplanar spacing were considered. Table 1 summarizes the main paleostresses obtained from different faulted sites.

4.2. Results of Tectonic Analysis. The Mobile Zone sites were the first to be analyzed in order to reconstruct Pan-African paleostresses. The data collected in the Stable Zone (the Eburnean basement complex and the lower sandy cover, 


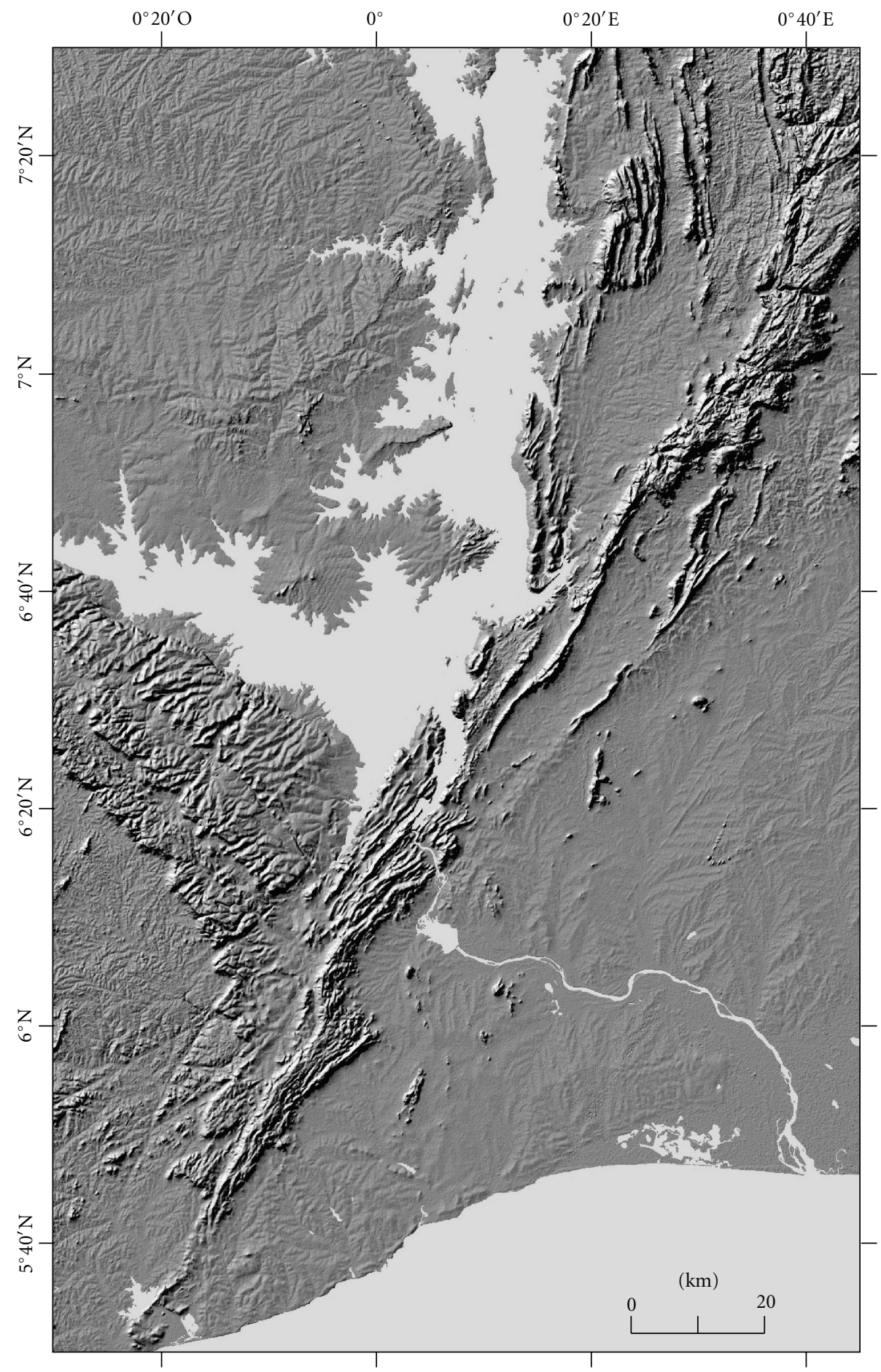

Figure 3: Satellite cover (MNT image) of southeast Ghana highlighting the juxtaposition of two highly contrasting morphostructural domains corresponding to the Pan-African Mobile Zone to the East and the Stable Zone (WAC and Volta Basin) to the West.

Figure 5) were then processed before comparing the results from the two zones.

4.2.1. Pan-African Mobile Zone Sites. Most of the sites in the Pan-African domain display a polyphase fracture network.
Some characteristics of such a fracture network are presented below.

Buem Structural Unit. The fracture in the Buem unit is well exposed in the Oterkpolu dolomitic carbonate quarry. 


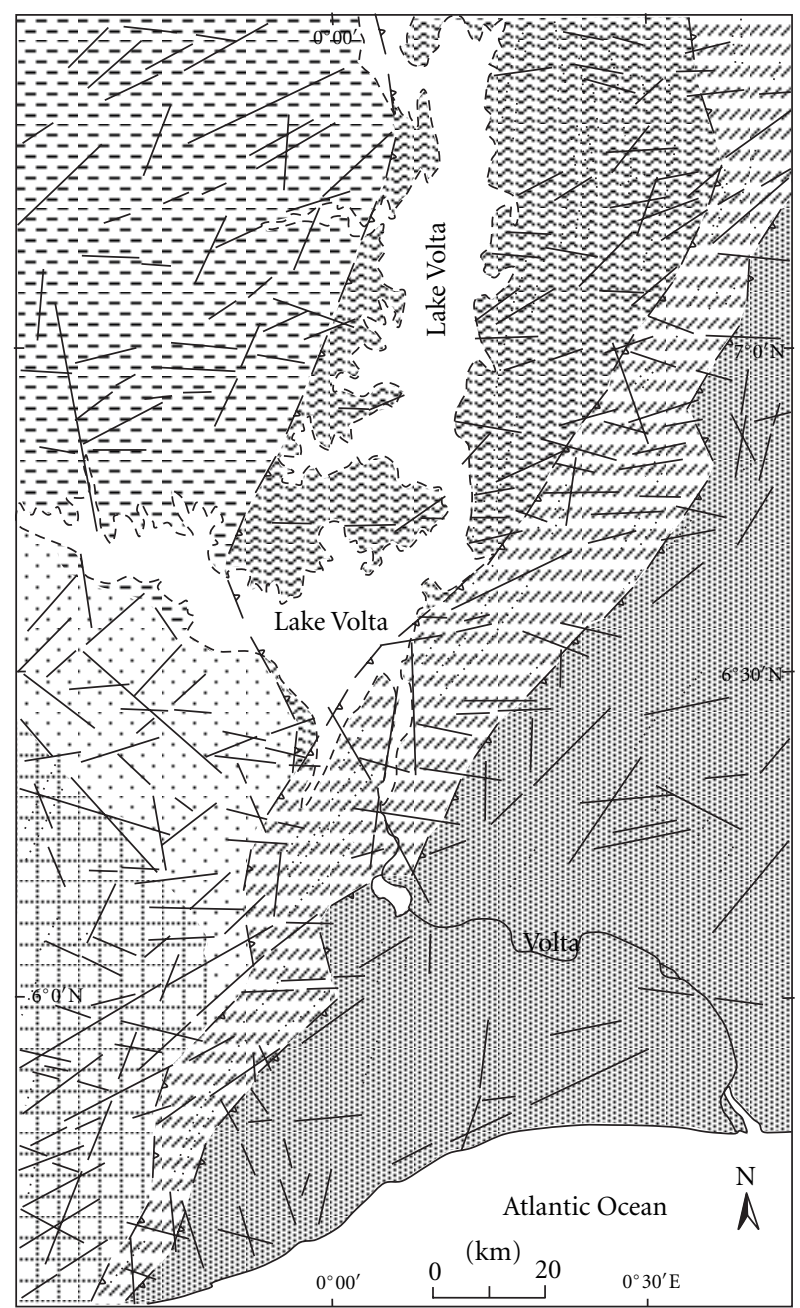

(a)

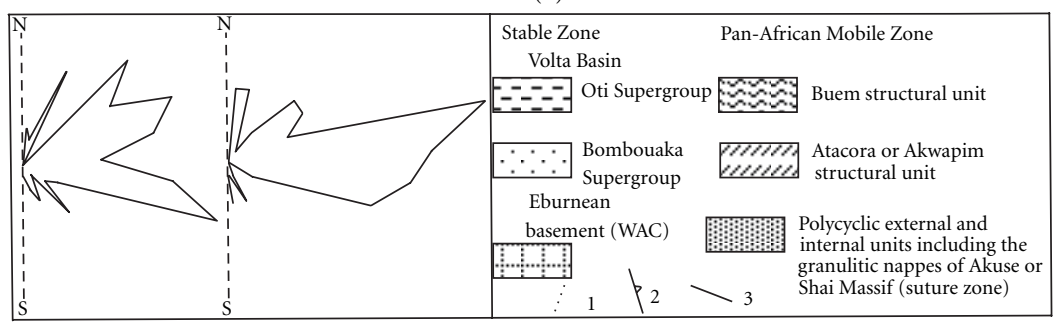

(b)

(c)

Figure 4: Lithostructural sketch highlighting the network of kilometric lineaments (a) and their distribution in the Stable Zone (b) and Mobile Zone (c): 1 = trace of Eburnean or Pan-African $(S n+1)$ foliation, 2 = major thrust contact, 3 = lineament.

The Bedded or banded bluish grey dolomitic carbonates show stratification planes that were strongly involved in decimetric (i.e., tens of centimeters) to metric (i.e., more than one meter) isoclinal folds (Figure 6(a)), generally overturned to the West with North-plunging submeridian axes (N175-20N). These Dn+1 folding structures are cut by two sets of conjugated strike-slip faults striking N90 to N110 (dextral) and N160 to N175 (sinistral), respectively. The result of analysis on this strike-slip system indicates a subhorizontal compressional N302-01 $\sigma 1$ axis (Figure 7(a); Table 1). A comparable compression is detected in the quartzites at the eastern margin of the Buem structural unit (Twum site, Figure 5) despite minor fracturing in these rocks (Table 1). It is important to note the very discrete presence of reverse faults associated with strike-slip faults in the beds of the Oterkpolu dolomitic carbonate (Figure 6(b)). These planes, shallowly dipping to the East, indicate westward thrusting, recognized as late or post-Dn+1 folding that predates the strike-slip faulting.

Akwapim Structural Unit. Seven sites such as road cuts and artisanal quarries are chosen for paleostress analysis 

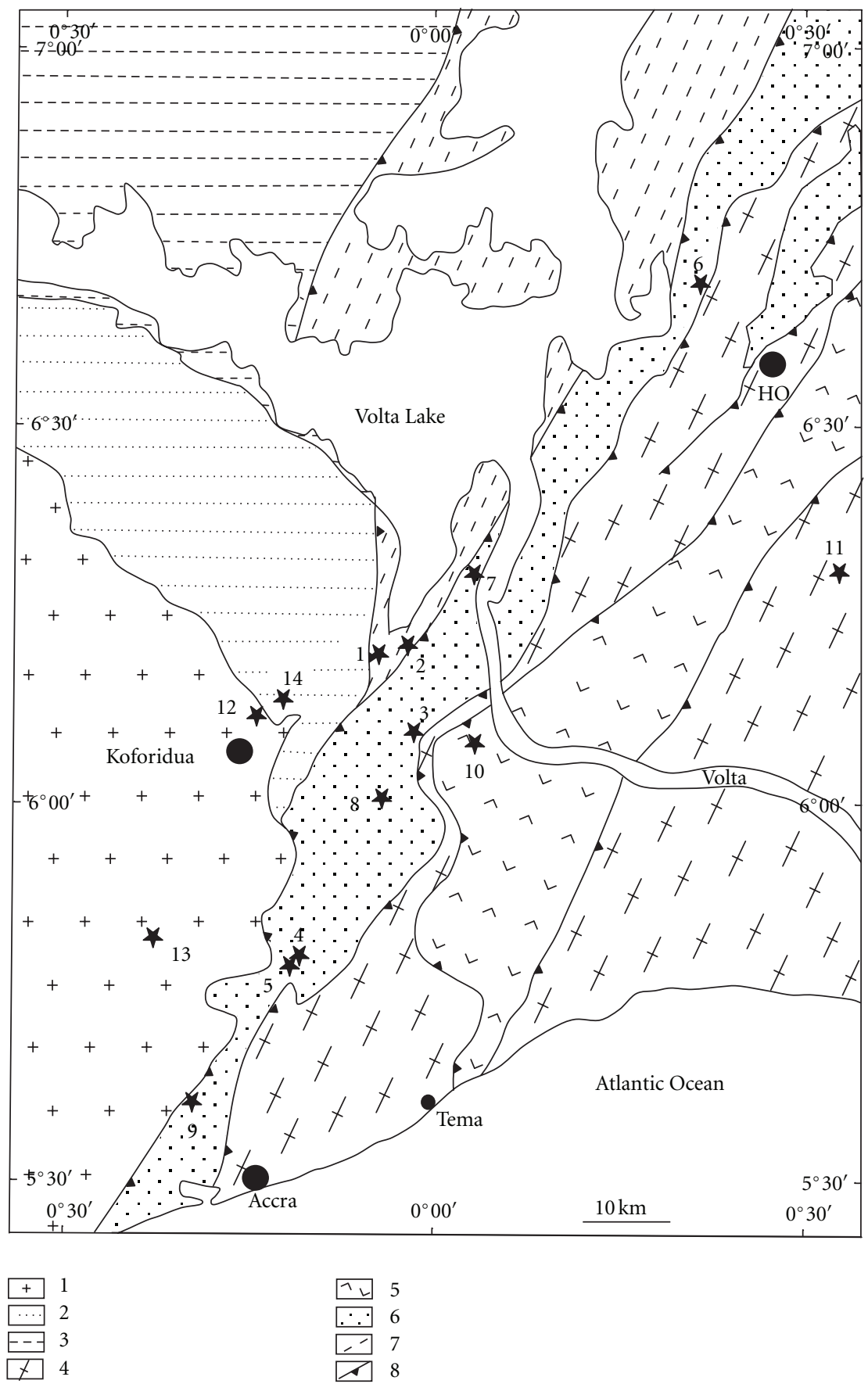

Figure 5: Location of the fourteen faulted sites ( 1 = Oterkpolu, $2=$ Twum, $3=$ Somanya, $4=$ Peduase-N, $5=$ Peduase-S, $6=$ Bani-Kpeve, 7 = Akosombo, 8 = Adukrom, $9=$ Ablikuma, $10=$ Akuse, $11=$ Ahunda, $12=$ Aboabo, $13=$ Nsawam, $14=$ Nkurakan) in different geological units in southeast Ghana ( 1 = Eburnean basement, 2 = Bombouaka Supergroup, $3=$ Oti Supergroup, $4=$ external and internal polycyclic nappes, 5 granulitic nappes of the suture zone, $6=$ Atacora or Akwapim structural unit, $7=$ Buem structural unit, $8=$ thrust contact.

(Figure 5). Numeros slickensides are well exposed in the shallow metasediments in this unit. At all these sites (Somanya, North Peduase, South Peduase, Bani-Kpeve, Adukrom, Akosombo, and Ablikuma), the kinematic criteria allow distinction of the following: (1) thrust planes, (2) several generations of strike-slip faults, and (3) normal fault planes.
Along the road section between Peduase and Ayimensa, many thrust planes are particularly well exposed. The identification of these planes as reverse faults allows the constitution of two northwest verging nappe piles. The analysis of these E-SE dipping reverse faults suggests that the nappe piles of the Akwapim Structural Unit (in Peduase 
TABLE 1: Synthesis of the results of the processing of fracture planes studied at all faulted sites in southeast Ghana. The table summarizes, for each site, the geographic coordinates, the rock type (Rt) involved ( $\mathrm{DC}=$ dolomitic carbonate, $\mathrm{S}-\mathrm{Q}=$ sandstone or quartzite, $\mathrm{MQ}=\mathrm{micaceous}$ quartzite, $\mathrm{QS}=$ quartzite and schist, $\mathrm{G}=$ granulite, $\mathrm{OG}=$ orthogneiss, $\mathrm{MG}=$ migmatitic gneiss, $\mathrm{M}-\mathrm{G}=$ migmatite and granite), the number of planes $(\mathrm{Np})$, plane type $(\mathrm{Pt})$ analyzed $(\mathrm{SSF}=$ strike-slip faults, $\mathrm{RF}=$ reverse faults, and $\mathrm{NF}=$ normal faults), and trend and plunge of main paleostress axes $(\sigma 1, \sigma 2, \sigma 3)$ obtained.

\begin{tabular}{|c|c|c|c|c|c|c|c|c|c|}
\hline \multirow{2}{*}{\multicolumn{2}{|c|}{ Site }} & \multicolumn{2}{|c|}{ Coordinates } & \multirow{2}{*}{ Rt } & \multirow{2}{*}{$\mathrm{Np}$} & \multirow{2}{*}{$\mathrm{Pt}$} & \multirow{2}{*}{$\sigma 1$} & \multirow{2}{*}{$\sigma 2$} & \multirow{2}{*}{$\sigma 3$} \\
\hline & & Latitude & Longitude & & & & & & \\
\hline \multicolumn{10}{|c|}{ Pan-African Mobile Zone } \\
\hline 1 & Oterkpolu & $\mathrm{N} 06^{\circ} 11^{\prime} 37.7^{\prime \prime}$ & W00 $04^{\prime} 42.9^{\prime \prime}$ & $\mathrm{DC}$ & 24 & SSF & $302-01$ & $37-73$ & $212-17$ \\
\hline 2 & Twum & N06 $10^{\prime} 29.9^{\prime \prime}$ & $\mathrm{W} 00^{\circ} 03^{\prime} 36.9^{\prime \prime}$ & S-Q & 12 & SSF & $109-25$ & $282-65$ & $18-03$ \\
\hline \multirow{4}{*}{3} & \multirow{4}{*}{ Somanya } & \multirow{4}{*}{$\mathrm{N}^{\circ} 6^{\circ} 05^{\prime} 54.5^{\prime \prime}$} & \multirow{4}{*}{$\mathrm{W} 00^{\circ} 01^{\prime} 45.6^{\prime \prime}$} & \multirow{4}{*}{ Q } & 33 & SSF & $37-13$ & $166-69$ & $303-16$ \\
\hline & & & & & 22 & SSF & $269-07$ & $143-78$ & 00-09 \\
\hline & & & & & 25 & SSF & $310-01$ & $44-80$ & $220-10$ \\
\hline & & & & & 9 & NF & $287-83$ & $177-02$ & $87-07$ \\
\hline \multirow{3}{*}{4} & \multirow{3}{*}{ Peduase- $\mathrm{N}$} & \multirow{3}{*}{ N05 $47^{\prime} 56.1^{\prime \prime}$} & \multirow{3}{*}{$\mathrm{W} 00^{\circ} 11^{\prime} 03.4^{\prime \prime}$} & \multirow{3}{*}{ QS } & 36 & $\mathrm{RF}$ & $303-02$ & 213-02 & $70-87$ \\
\hline & & & & & 23 & SSF & $20-06$ & $146-79$ & $289-08$ \\
\hline & & & & & 23 & SSF & $260-03$ & $161-73$ & $350-17$ \\
\hline \multirow{3}{*}{5} & \multirow{3}{*}{ Peduase-S } & \multirow{3}{*}{ N05 $47^{\prime} 28.8^{\prime \prime}$} & \multirow{3}{*}{$\mathrm{W} 00^{\circ} 11^{\prime} 33.1^{\prime \prime}$} & \multirow{3}{*}{ QS } & 31 & SSF & 141-02 & $31-84$ & $231-06$ \\
\hline & & & & & 47 & $\mathrm{NF}$ & $259-72$ & $52-16$ & $144-08$ \\
\hline & & & & & 21 & SSF & 199-09 & $74-74$ & $291-13$ \\
\hline \multirow[t]{2}{*}{6} & \multirow[t]{2}{*}{ Bani-Kpeve } & \multirow[t]{2}{*}{ N06 $40^{\prime} 78.6^{\prime \prime}$} & \multirow[t]{2}{*}{$\mathrm{E} 00^{\circ} 21^{\prime} 14.0^{\prime \prime}$} & \multirow[t]{2}{*}{ Q } & 28 & SSF & $158-04$ & $53-75$ & $249-15$ \\
\hline & & & & & 27 & NF & $262-81$ & $13-03$ & $104-08$ \\
\hline 7 & Akosombo & $\mathrm{N}^{\circ} 6^{\circ} 18^{\prime} 16.0^{\prime \prime}$ & $\mathrm{E} 00^{\circ} 03^{\prime} 18.3^{\prime \prime}$ & OS & 22 & SSF & $210-06$ & $95-76$ & $301-13$ \\
\hline ( & 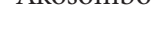 & & & & 15 & $\mathrm{NF}$ & $94-82$ & 01-00 & 271-08 \\
\hline 8 & Adukrom & $\mathrm{N}^{\circ} 06^{\circ} 00^{\prime} 40.6^{\prime \prime}$ & W00 $03^{\prime} 59.4^{\prime \prime}$ & QS & 32 & SSF & 149-03 & $48-76$ & $239-14$ \\
\hline 9 & Ablikuma & N05 $37^{\prime} 03.9^{\prime \prime}$ & W00 $10^{\prime} 39.3^{\prime \prime}$ & Q & 13 & SSF & $202-01$ & $301-83$ & $111-06$ \\
\hline (5) & КणाК & 18 & 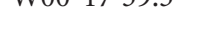 & $Q^{2}$ & 11 & SSF & $64-03$ & $307-84$ & $154-06$ \\
\hline 10 & Akuse & $\mathrm{N} 06^{\circ} 05^{\prime} 14.9^{\prime \prime}$ & W00 $04^{\prime} 04.7^{\prime \prime}$ & G & 9 & SSF & $186-21$ & $356-69$ & $94-03$ \\
\hline & & & & S & 18 & SSF & $142-02$ & $49-60$ & $233-30$ \\
\hline 11 & Ahunda & $\mathrm{N}^{\circ} 6^{\circ} 18^{\prime} 29.9^{\prime \prime}$ & $\mathrm{E} 00^{\circ} 32^{\prime} 39.7^{\prime \prime}$ & OG & 14 & SSF & 174-02 & $288-86$ & 84-04 \\
\hline & & & & Zone & & & & & \\
\hline 12 & Aboabo & $\mathrm{N} 06^{\circ} 07^{\prime} 30.1^{\prime \prime}$ & $\mathrm{W} 00^{\circ} 13^{\prime} 56.9^{\prime \prime}$ & MG & 10 & SSF & $120-09$ & $274-80$ & $29-04$ \\
\hline & & & & & 18 & SSF & 173-02 & $290-86$ & $83-04$ \\
\hline 13 & Nsawam & N05 $48^{\prime} 58.9^{\prime \prime}$ & $\mathrm{W} 00^{\circ} 22^{\prime} 24.4^{\prime \prime}$ & $M-G$ & 30 & SSF & $340-07$ & $234-66$ & $73-23$ \\
\hline 14 & Nkurakan & N06 $08^{\prime} 06.0^{\prime \prime}$ & $\mathrm{W} 00^{\circ} 12^{\prime} 10.4^{\prime \prime}$ & S-Q & 24 & SSF & $02-14$ & $137-70$ & $269-13$ \\
\hline
\end{tabular}

sector) were emplaced during the maximum N302-02 $\sigma 1$ compression (Figure 7(b); Table 1).

The thrust contacts in the Peduase sector are cut by numerous strike-slip faults related to two or three conjugated sets in the Akwapim quartzites. The relatively old system includes sets of major planes with mineral recrystallization (quartz, sericite ). These planes, with submeridian and NESW (N40 to N75) trends, are dextral and sinistral respectively (Figure 6(c)). These early strike-slip faults indicate a compression due to a major $\sigma 1$ subhorizontal paleostress trending N20 to N40 (Figure 7(c); Table 1). The trend of this principal paleostress appears to be confirmed at the Somanya site-N35 trending tension gashes (Figure 6(d)) that are deformed by subsequent $\mathrm{Dn}+2$ folding.

Two families of dry fractures corresponding to conjugated planes are superimposed on the first strike-slip faults identified above. They are (1) NE-SW trending (N40 to N65) dextral and ESE-WSW trending (N105 to N125) sinistral, and (2) ENE-WSW to ESE-WNW (N80 to N125) dextral and N140 to N165 or N350 to N10 sinistral (Figures 7(d) and $7(\mathrm{e}))$. The processing of the data relative to these last two systems of strike-slip faults suggest to relate the initial superposition of fractures to a subhorizontal $\sigma 1$ axis trending ENE-WSW to E-W (N260 to N270). The latest strike-slip faults rather appear to be due to systems of paleostresses whose major axes are NW-SE (N120) or NNW-SSE (N160). These axes are sometimes materialized by extensional joints (Figure 6(d)).

Finally, the Akosombo, Bani-Kpeve, Somanya, and Peduase sites display tectoglyphe bearing planes of characteristic normal faults (Figure 6(e)). This is the last generation of fractures that are generally found with submeridian to NESW trends as well as SE-NW to ESE-WNW trends (Figures $7(\mathrm{f})$ and $7(\mathrm{~g}))$. They can be associated with late reactivations of normal faulting motion of the former strike-slip fault planes. These movements clearly postdate all the strike-slip 


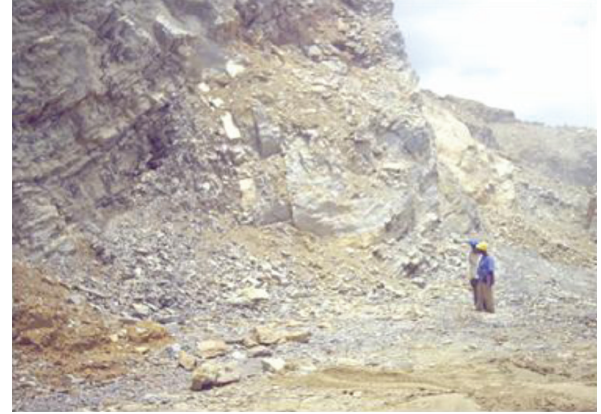

(a)

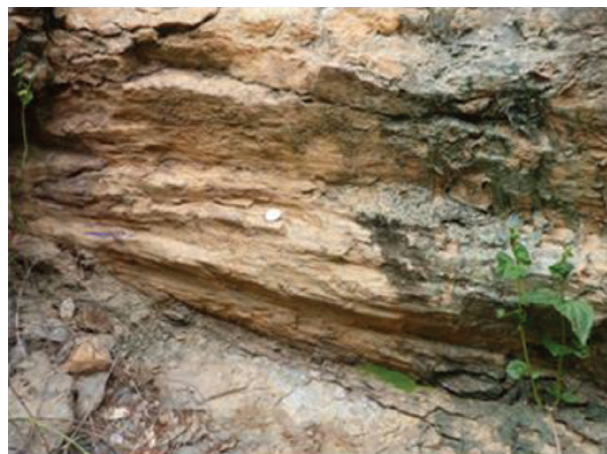

(c)

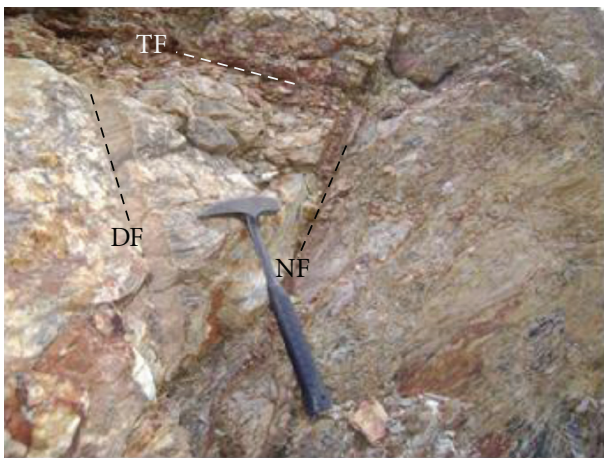

(e)

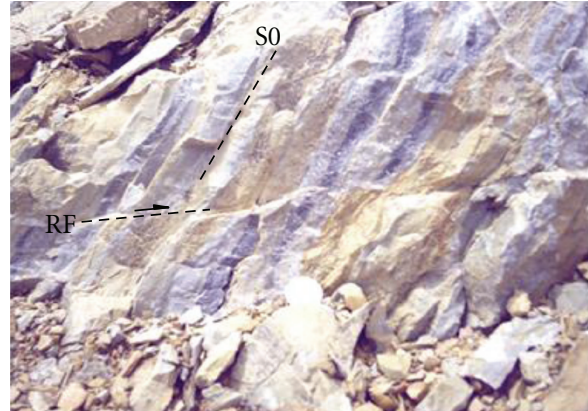

(b)

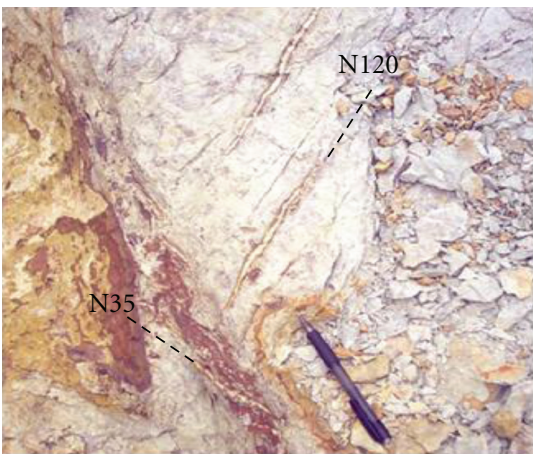

(d)

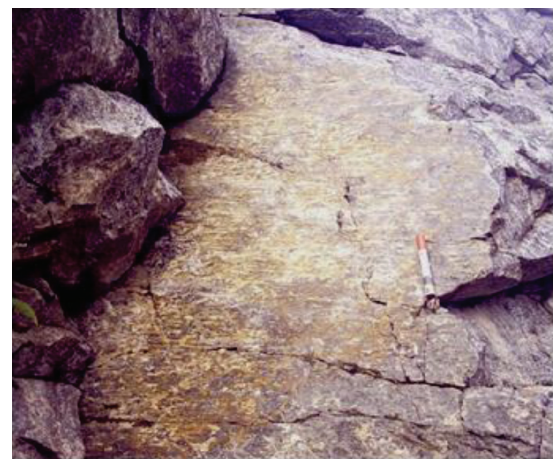

(f)

FIgURE 6: Structures of ductile and brittle deformations observed in southeast Ghana: (a) metric folds overturned to West and with submeridian axes in dolomitic carbonate of the Oterkpolu quarry; (b) N20-18E reverse fault plane in dolomitic carbonate of the Oterkpolu quarry (S0, N05-65E); (c) major N60-80NW sinistral strike-slip fault, with channel-like striation plunging at $15^{\circ} \mathrm{NE}$ (quartzite in a road section at Akosombo); (d) two generations of extension joints trending N35 and N120, inscribed on a Dn+2 decimetric fold (N60-20NE axis) and materializing the NE-SW and SE-NW $\sigma 1$ axes of major paleostresses of different ages (Somanya quarry); (e) late normal fault (Fn, N55-60SE) cutting a thrust plane (Fc) and a sinistral strike-slip fault (Fd, road section at Peduase-S site); (f) slickenside of a major sinistral strike-slip fault (N10-75W) with striations plunging at $12^{\circ}$ to the South and superposed amphibolite and fibrous mineral lineation (Nsawam quarry).

faulting and seem to link to paleostresses indicating an E-W to SE-NW extension (Figures 7(f) and 7(g); Table 1).

Suture Zone and Internal Structural Units. The fracture data from the eastern sector (suture zone and internal structural units) were collected at an industrial granulite quarry in the Shai hills (Akuse site) and in the Hô augen gneiss (Ahunda site, Figure 5). Decimetric to metric bands of garnet-granulites are mainly cut by fractures with a strikeslip kinematics and the slickensides are carpeted with biotite.
These are N115 to N125 dextral and submeridian sinistral conjugated planes. These two families of major planes reflect a SE-NW (N142) compressional $\sigma 1$ axis. Moreover, N40 to N60 dextral and N160 to N175 sinistral minor fractures indicate a much later compression related to a maximum main paleostress $\sigma 1$ oriented N184-22 (Table 1).

At the Ahunda quarry, the SE-NW dextral and N20 to N40 sinistral conjugated strike-slip faults were identified with a primary N170 $\sigma 1$ trend (Figure 7(h); Table 1). In addition to these strike-slip faults, displacements were also 


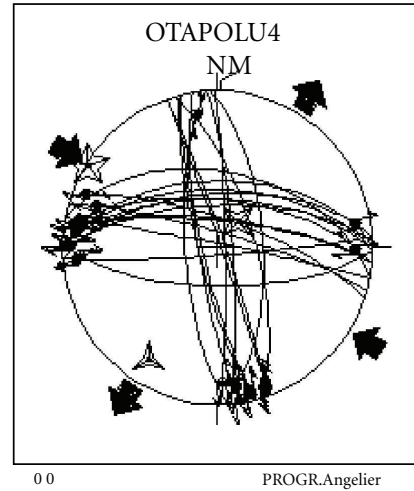

(a)

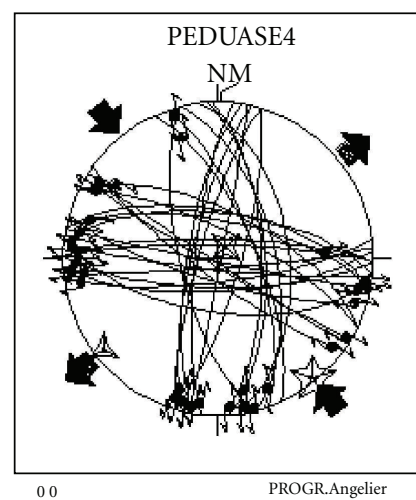

(e)

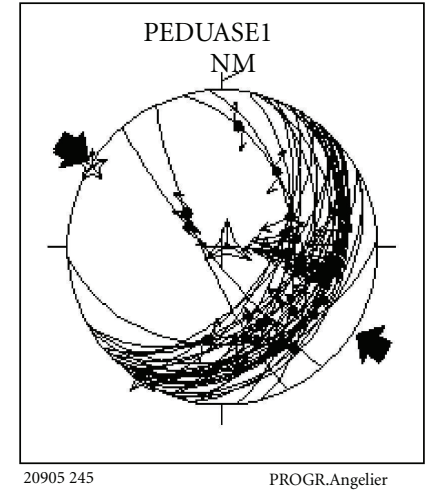

(b)

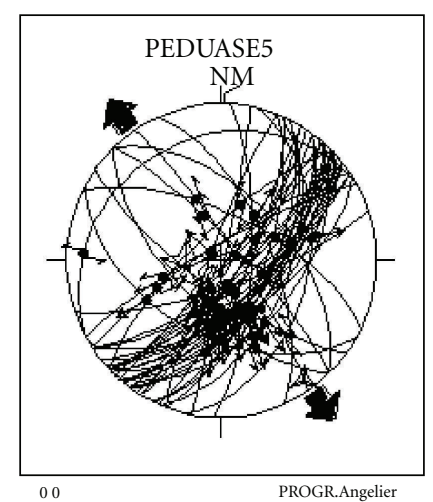

(f)

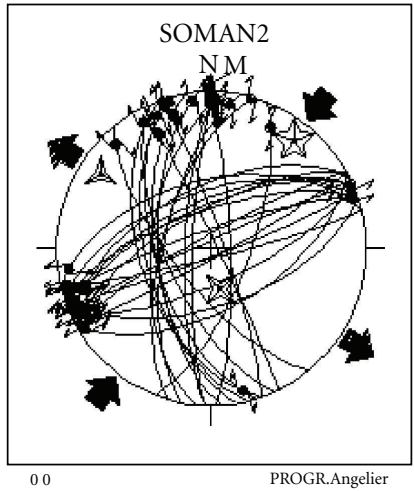

(c)

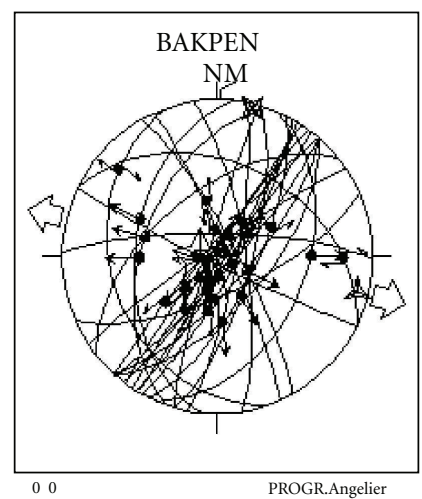

(g)

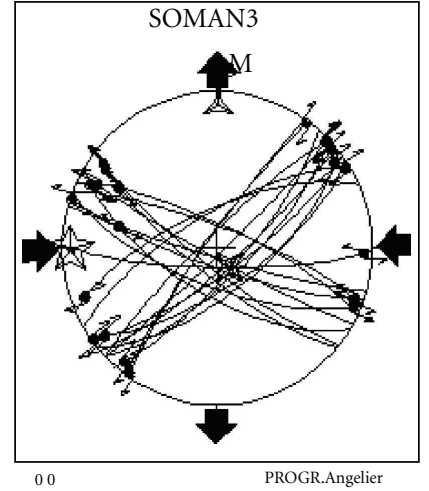

(d)

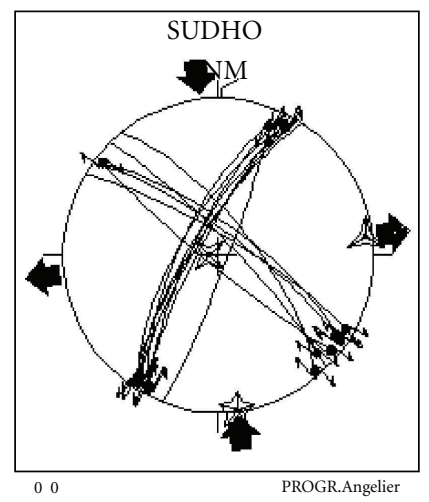

(h)

Figure 7: Stereograms obtained by processing striated fracture planes recorded in the Mobile Zone in southeast Ghana: (a), sets of strikeslip faults in dolomitic carbonates of the Oterkpolu quarry; (b), reverse faults or thrust planes in nappe pile of Peduase; (c), sets of primary strike-slip faults in quartzites at the Somanya quarry; (d) and (e), sets of secondary strike-slip faults in quartzites and schists (Somanya quarry and Peduase-N road section); (f) and (g), normal faults in quartzites and schists (Peduase-S and Bani-Kpeve road sections); (h) sets of strike-slip faults in augen gneiss at the Ahunda quarry. The stars represent poles of the $\sigma 1$ (star with 5 branches), $\sigma 2$ (star with 4 branches), and $\sigma 3$ (star with 3 branches) of paleostress axes.

identified on late N60 to N75 normal fault planes comparable to those due to an extensional movement in the quartzites of the Akwapim structural unit.

Pan-African Mobile Zone in Southeast Ghana. From the analysis of the striated planes in the Mobile Zone in southeast Ghana, three or four compressional axes and one late extensional axis can be identified (Figure 7). These axes resulted from the following: (1) thrust planes indicating reverse faults in the soles of nappes or thrust slices in the Peduase sector, (2) strike-slip faulting representing families of conjugated fractures attributed to distinct episodes, and (3) late normal faults. The first generation of strike-slip faults indicates a NE-SW compressional axis. Following this, the frontal units of the orogeny recorded two successive paleostress systems with primary E-W and SE-NW to SSENNW trending $\sigma 1$ axes. The number of fracturing episodes recorded by the Akwapim quartzitic facies appears greater than that in the other Pan-African units (Figure 7; Table 1), which could be explained by differences in the competence of the affected rocks.
The paleostresses deduced from the analysis of the fracture planes in the Buem dolomitic carbonates (Oterkpolu site) are comparable to those from the last episodes in the Akwapim structural unit. Similarly, the paleostress systems represented by the strike-slip faults identified in the eastern part (suture zone and internal structural units) are superposable on the paleostresses recorded in the Buem. The development of late strike-slip faults thus appears to be common in the Pan-African Mobile Zone.

The imprint of the E-W to SE-NW extensional episode suggests normal faulting. This post-Pan-African or very late tectonic episode is responsible for the reactivation of former fracture planes, leading to the superposition of high pitch striations that is incompatible with the primary movements.

4.2.2. Stable Zone Sites. Limited outcrops are discovered in the Stable Zone. Consequently only three faulted sites (Aboabo, Nsawam, and Nkurakan) were studied in the Eburnean basement complex and in the basal part of the lower megasequence of the Volta Basin (Figure 5). The fracture data collected at these sites therefore do not 
comprehensively reflect the complexity of the lineament network identifiable at the satellite-image scale. However, the resulting data are steel very useful and important.

Aboabo Sector. The Aboabo industrial quarry reveals migmatitic paragneisses with quartzo-feldspathic leucozones and dark centrimetric boudins. These facies of the Eburnean basement complex are also cut by two generations of aplitic or pegmatitic veins. More recent NE-SW centrimetric veins cut through the sinistral submeridian strike-slip faults. In the quarry, two fracture generations were identified. The older planes are generally covered with biotite or amphibole and quartz lineations. The latter ones are often associated with recrystallized fibres parallel to the subhorizontal lineation. The tectoglyphes indicate homogeneous strikeslip movements which appear to reflect late reactivations of older planes. The conjugated strike-slip faults are SE-NW trending (N120 to N155) dextral and NE-SW trending (N30 to N50) sinistral, indicating a compression with $\sigma 1$ axis orienting N172-02 (Figure 8(a); Table 1). The second slickenside generations are dry types and include two families of ENE-WSW trending (N70-N80) dextral and SSE-NNW trending (N160-N170) sinistral strike-slip faults. Analysis on these fracture planes led to discover a system of paleostress axes, with one main N120-02 $\sigma 1$ axis (Table 1).

Nsawam Sector. In the Nsawam quarry, dark gneissomigmatitic facies of the Eburnean basement complex display numerous amphibolitic inclusions. They are associated with a complex of metric veins of leucogranites, aplites, and pegmatites. The assemblage is cut by the first generation type fractures as identified at the Aboabo site (Figure 6(f)). They are families of conjugated submeridian to NE-SW sinistral and ESE-WSW to SE-NW (N105 to N130) dextral strike-slip faults. The processing of the data indicates a compression with a main paleostress $\sigma 1$ orienting N340-07 (Figure 8(b), Table 1).

Volta Basin. Outcrops at the Nkurakan site are characterized by massive bands of quartzites or quartzitic sandstones with limited black shale intercalations. These facies belong to the Mpraeso Formation (lower part of Bombouaka or Kwahu Supergroup, [5]). Decimetric bands with SE dips (N5035SE) are cut by strike-slip faults that are assembled around the ESE-WNW to SE-NW trending (N115 to N140) dextral and ENE-WSW to E-W trending (N75 to N95) sinistral. These strike-slip faults are resulted from a compression, with a main N-S and subhorizontal (N02-14) $\sigma 1$ axis (Figure 8(c), Table 1). This compressional axis is comparable to those derived from analysis of the fracture planes recorded in the facies of the Eburnean basement complex (at the Aboabo and Nsawam sites).

Stable Zone in Southeast Ghana. The Eburnean basement complex and the lower part of its cover display the imprints of two fracturing episodes due to compressions. The main episode is attributable to a system of paleostresses with a principal N-S to NNW-SSE trending $\sigma 1$ axis (Figure 8;
Table 1). On the slickensides of the principal strike-slip faults, recrystallized fibres or biotite orientations suggest that these paleostresses correspond to a late movement related to development of amphibole and quartz lineation (older late-Eburnean or pre-Pan-African movement associated with a much higher ambient temperature). The determined paleostress axes are superposable on the last Pan-African compression phases. The other episode is expressed us fracture planes indicating an ESE-WNW to SE-NW trending compressional axis (Aboabo site; Table 1). Finally, some tectoglyphe bearing planes of normal faults can be interpreted as markers of a late extensional episode identified at the PanAfrican Mobile Zone sites.

\section{Interpretation}

In summary, the set of fractures observed in the frontal part of the Dahomeyide Belt in southeast Ghana are resulted from four Pan-African compressive phases followed by a very late or post-Pan-African extension probably of Devonian age [7].

The compressive episodes are materialized by west verging thrust planes and conjugated strike-slip faults. The latter allow determination of the main paleostress $\sigma 1$ axes, with successively NE-SW, ENE-WSW to E-W, and SE-NW to SSE-NNW trends. The order of involvement of the main paleostresses is defined based on the relative ages of the recorded strike-slip faults. The orientation of the different axes of the main paleostress $\sigma 1$ allows comparison with different Pan-African paleostresses recorded in northern Togo [13]. Comparing the Pan-African paleostresses determined in two segments of the Dahomeyide Belt (Table 2), the dense fracture network identified in the frontal part of the Mobile Zone in southeast Ghana should be produced from the superposition of four deformation phases $(\mathrm{Dn}+1$ to $\mathrm{Dn}+4)$. As in northern Togo, the Pan-African compressional axis underwent a major clockwise rotation (of more than $140^{\circ}$ ) during the erection of the southern segment of the Dahomeyide Belt. Particularly noticing, the average NE-SW structural trend of this segment is not in agreement with the NE-SW compressive axis due to the $\mathrm{Dn}+1$ deformation phase (tangential or nappe stacking phase). Indeed, the orientations of the thrust planes and the northwest verging nappes (Peduase nappe piles) rather reflect a primary N302$02 \sigma 1$ paleostress axis (Figure 7(b)), which is superposable on the main paleostress of $\mathrm{Dn}+3$ phase (Table 2). Far from supporting the results of [46], suggesting a NE-SW Dahomeyide nappe piling, this conclusion seems to contradict the suggestion that nappe stacking in northern Togo took place along an ENE-WSW axis [10, 13]. At a regional scale (Figures 3 and 4), it is striking that the southern segment of the Dahomeyide Belt is not in conformity with the submeridian appearance of the whole orogeny. This structural trend of the southernmost segment probably corresponds to a strong transposition related to the $\mathrm{Dn}+3$ and $\mathrm{Dn}+4$ Pan-African compressions. It is this transposition that justifies the present orientation of the main paleostress $\sigma 1$ which is related to the emplacement of the nappes in southeast Ghana.

In the cratonic domain and its cover (Stable Zone), only two compressional axes might be defined. They are 


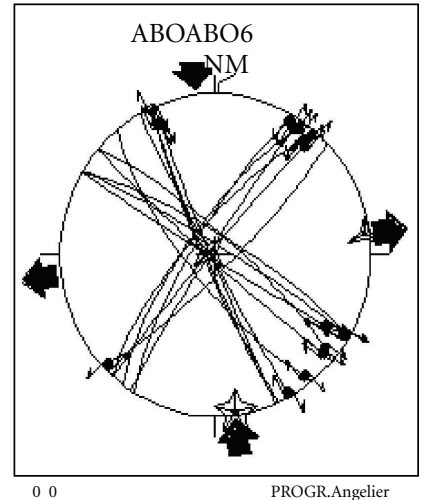

(a)

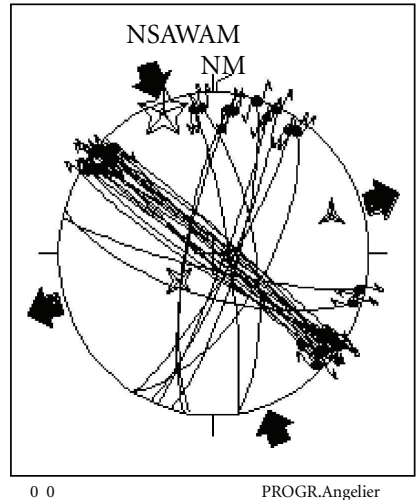

(b)

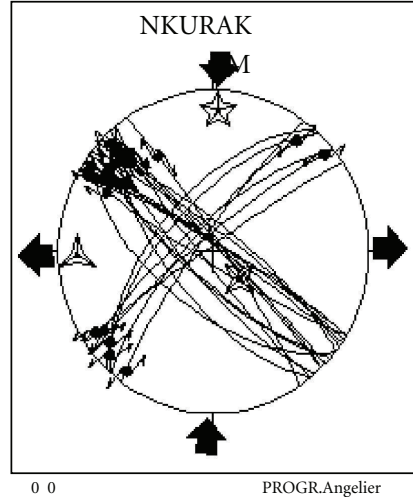

(c)

FIGURE 8: Stereograms obtained by processing striated planes recorded in the Eburnean basement complex and the basal part of the Volta Basin in southeast Ghana: (a), sets of strike-slip faults in migmatitic paragneisses of the Aboabo quarry; (b), sets of strike-slip faults in the Eburnean basement complex of the Nsawam quarry; (c), sets of strike-slip faults in quartzites at the Nkurakan quarry. The stars represent poles of the $\sigma 1$ (star with 5 branches), $\sigma 2$ (star with 4 branches), and $\sigma 3$ (star with 3 branches) paleostress axes.

TABle 2: Correlation between the main Pan-African compressional axes in northern Togo and southeast Ghana.

\begin{tabular}{|c|c|c|c|}
\hline \multirow[t]{2}{*}{$\begin{array}{l}\text { Pan-African deformation } \\
\text { phases }\end{array}$} & \multirow{2}{*}{$\begin{array}{c}\text { Compressional axis }(\sigma 1) \text { reconstructed in } \\
\text { northern Togo (according to work by Affaton } \\
\text { et al., [12]; Tairou, [10]; Tairou et al., [13]) } \\
\text { Mobile Zone }\end{array}$} & \multicolumn{2}{|c|}{ Compressional axis $(\sigma 1)$ reconstructed in southeast Ghana } \\
\hline & & Mobile Zone & Stable Zone \\
\hline $\mathrm{Dn}+1$ & NE-SW to ENE-WSW (N40 to N80) & $\begin{array}{l}\text { NNE-SSW to NE-SW (N20 } \\
\text { to N40) }\end{array}$ & \\
\hline $\mathrm{Dn}+2$ & ESE-WNW (N100 to N115) & $\begin{array}{l}\text { ENE-WSW to E-W (N80 to } \\
\text { N90) }\end{array}$ & \\
\hline $\mathrm{Dn}+3$ & SE-NW (N120 to N130) & SE-NW (N120 to N130) & SE-NW (N120) \\
\hline $\mathrm{Dn}+4$ & SE-NW to SSE-NNW (N140 to N150) & $\begin{array}{l}\text { SE-NW to SSE-NNW } \\
\text { (N140 to N175) }\end{array}$ & $\begin{array}{l}\text { SSE-NNW to S-N (N340 } \\
\text { to N02) }\end{array}$ \\
\hline
\end{tabular}

comparable to those related to the $\mathrm{Dn}+3$ and $\mathrm{Dn}+4$ PanAfrican episodes (Table 2). The common expression of these last phases of deformation across each of the structural units of the Dahomeyide Belt implies that reactivation of the eastern margin of the West African craton itself was due to these episodes. Indeed, the frontal margin of the Dahomeyide Belt was overthrusted onto this cratonic margin during the first Pan-African deformation $(\mathrm{Dn}+1$ and $\mathrm{Dn}+2)$ and they together underwent the $\mathrm{Dn}+3$ and $\mathrm{Dn}+4$ episodes.

In short, the partial reactivation of the cratonic margin in southeast Ghana occurred during the major rotation peak of the Pan-African compressional axis. Two successive events materialize this reactivation as follows: (1) the development of ENE-WSW and SSE-NNW fractures indicating a main N120-02 $\sigma 1$ paleostress axis, typical of the SE-NW compression of the Dn+3 Pan-African phase; (2) the strikeslip reactivation of submeridian to NE-SW and E-W to SENW fracture planes associated with a primary compressive paleostress axis (N172-02 $\sigma 1$ and N02-14 $\sigma 1$ at Aboabo and Nsawam sites, resp.) that can be attributed to the final Pan-African Dn+4 compression. These late Pan-African reactivation planes belong to a fracture network known in the whole West-African Craton, particularly in Burkina Faso [47]. They are associated with doleritic veins whose emplacement is related to late Eburnean to pre-Pan-African events and to the Central Atlantic prerifting [11].

In southeast Ghana, the late extensional movement is materialized by normal faults that are particularly well developed in the quartzites of the Akwapim structural unit. It is also responsible for normal faulting reactivations of strike-slip fault planes resulting from Pan-African compressional episodes. Popoff [48] correlated extension markers to the fracturing of an overstretching continent in response to the relaxation of the Pan-African orogenic stresses during the Middle Cambrian. Hitherto, such extension indicators were not reported in the northern and central segments of the Dahomeyide Belt [12, 13]. The development of such extensional markers in the southern segment suggests that they were resulted from a Paleozoic faulting tectonics which led to the Devonian deposits in Ghana (Accra, Sekondi, and Takoradi Basins) and at the base of the sedimentary sequence of the Keta and Togo coastal Basins $[1,9,12,49-52]$. Therefore, this extension might be considered as a precursor event of the Jurassic rifting 
that resulted in the opening of the Central Atlantic and the development of the Benue Trough in Nigeria.

\section{Conclusion}

The analysis of the dense fracture network in southeast Ghana has led the reconstitution of the superposition of PanAfrican to late- or post-Pan-African paleostresses recorded in the frontal margin of the Pan-African Dahomeyide Belt and the southeastern margin of the West-African Craton (WAC). Above a clear morphostructural contrast, the distribution of lineaments indicates a juxtaposition of two very different domains and suggests the coexistence of Eburnean and Pan-African fractures in the stable domain constituted by a part of the WAC (of Archean to Paleoproterozoic age) and of its Neoproterozoic cover. In the lithostructural units of the Pan-African orogeny, the recorded fractures define four successive compressional axes oriented NE-SW, ENE-WSW, SE-NW, and SSE-NNW to S-N. These axes are comparable to those which are well known in the northern and central segments of the Dahomeyide Belt and correlated with four Pan-African tectogenesis phases $(\mathrm{Dn}+1$ to $\mathrm{Dn}+4)$. As in northern Togo, the superposition of the paleostresses deduced from these deformation phases defines a major clockwise rotation (of more than $140^{\circ}$ ) of the compressional axis during the erection of the southern segment of the belt, while a rotation of 90 to $110^{\circ}$ was expressed in the central segment of this orogen.

Despite the complexity of the lineament network characterizing the cratonic margin and its cover in southeast Ghana, the studied sites in this Stable Zone only present a few families of fractures and reworked strike-slip faults. An analysis of these structural elements has led to determine major paleostresses $\sigma 1$ axes which are superposable to those attributed to the Pan-African Dn+3 and Dn+4 compressive phases. These results suggest that the reactivation of Eburnean fractures is coeval with the last two phases of PanAfrican tectogenesis.

In southeast Ghana, the peculiarity of brittle deformation is the recording of a post-Pan-African extensional phase. This late normal faulting corresponds to an E-W to SENW extension. It may be attributed to early (Cambrian to Devonian) episodes of the major Mesozoic fragmentation of the Western Gondwana. This fragmentation has resulted in the birth of the Central Atlantic and the Benue Trough in Jurassic.

\section{References}

[1] P. Affaton, M. A. Rahaman, R. Trompette, and J. Sougy, "The dahomeyides orogen: tectonothermal evolution and relationships with the Volta basin," in The West-African Orogen and Circum Atlantic Correlatives, Dallmayer and Lécorché, Eds., pp. 107-122, 1CGP, IUGS, UNESCO.

[2] G. Rocci, G. Bronner, and M. Deschamps, "Crystalline basement of the West African craton," in The West-African Orogen and Circum Atlantic Correlatives, Dallmayer and Lécorché, Eds., pp. 31-61, 1CGP, IUGS, UNESCO, 1991.
[3] R. Trompette, "Neoproterozoic (600 Ma) aggregation of Western Gondwana: a tentative scenario," Precambrian Research, vol. 82, no. 1-2, pp. 101-112, 1997.

[4] F. Kalsbeek, D. Frei, and P. Affaton, "Constraints on provenance, stratigraphic correlation and structural context of the Volta basin, Ghana, from detrital zircon geochronology: an Amazonian connection?" Sedimentary Geology, vol. 212, no. 1-4, pp. 86-95, 2008.

[5] J. N. Carney, C. J. Jordan, C. W. Thomas, D. J. Condon, S. J. Kemp, and J. A. Duodo, "Lithostratigraphy, sedimentation and evolution of the Volta Basin in Ghana," Precambrian Research, vol. 183, no. 4, pp. 701-724, 2010.

[6] P. Affaton, "Etude géologique et structurale du Nord-OuestDahomey, du Nord-Togo et du Sud-Est de la Haute-Volta. Thèse de 3e Cycle," Trav. lab. Sci. Terre St Jérôme, Marseille. Fr., Sér. B., 10, 217p, 1975.

[7] P. Affaton, "Le basin des Volta (Afrique de 1'Ouest): une marge passive d'âge Protérozoïque supérieur, tectonisée au Panafricain (600 $\pm 50 \mathrm{Ma}$ )," Editions ORSTOM, Collection Etudes et Theses, Paris, 500p, 1990.

[8] N. Simpara, Etude géologique et structurale des unités externes de la chaîne panafricaine (600 Ma) des Dahomeyides dans la région de Bassar (Togo) [Ph.D. thesis], University of AixMarseille III, 1978.

[9] P. Affaton, J. Sougy, and R. Trompette, "The tectonostratigraphic relationships between the upper precambrian and lower paleozoic volta basin and the pan-african dahomeyide orogenic belt (West Africa)," American Journal of Science, vol. 280, no. 3, pp. 224-248, 1980.

[10] M. S. Tairou, La tectonique tangentielle panafricaine au NordTogo [Ph.D. thesis], Université de Lomé, 2006.

[11] P. Affaton, P. Gaviglo, and A. Pharisat, "Réactivation du craton ouest-africain au panafricain : paléocontraintes déduites de la fracturation des grès néoprotérozoïques de Karey Gourou (Niger, Afrique de l'Ouest)," Comptes Rendus de l'Académie des Sciences, vol. 331, pp. 609-614, 2000.

[12] P. Affaton, J. P. Gelard, and N. Simpara, "Paléocontraintes enregistrées par la fracturation dans l'unité structurale de l'Atacora (Chaîne Panafricaine des Dahomeyides, Togo)," Comptes Rendus de l'Académie des Sciences, vol. 312, pp. 763768, 1991.

[13] M. S. Tairou, P. Affaton, J.-P. Gélard, R. Aite, and B. E. Sabi, "Panafrican brittle deformation and palaeostress superposition in northern Togo (West Africa)," Comptes RendusGeoscience, vol. 339, no. 13, pp. 849-857, 2007.

[14] L. Latouche and J. Fabre, "Le Précambrien du craton ouest-africain," in Géologie du Sahara Occidental et Central. Protérozö̈que Inférieur de la Dorsale de Guinée, J. Fabre, Ed., vol. 108 of Tervuren, African Geosciences, pp. 15-72, Musée Royale de l'Afrique Centrale, Belgique, 2005.

[15] B. Bessoles, “Géologie de l'Afrique," Le craton Ouest Africain. Mém. BRGM 88, 403p, 1977.

[16] E. K. Agyei, J. E. J. M. Van Landewijk, R. L. Armstrong, J. E. Harakal, and K. L. Scott, "RbSr and KAr geochronometry of South Eastern Ghana," Journal of African Earth Sciences, vol. 6, no. 2, pp. 153-161, 1987.

[17] W. Hirdes and D. W. Davis, "First U-Pb zircon age of extrusive volcanism in the Birimian Supergroup of Ghana/West Africa," Journal of African Earth Sciences, vol. 27, no. 2, pp. 291-294, 1998.

[18] F. Kalsbeek, P. Affaton, B. Ekwueme, R. Frei, and K. Thrane, "Geochronology of granitoid and metasedimentary rocks from Togo and Benin, West Africa: comparisons with NE Brazil," Precambrian Research, pp. 218-233, 2012. 
[19] S. B. Dampare, T. Shibata, D. K. Asiedu, S. Osae, and B. Banoeng-Yakubo, "Geochemistry of Paleoproterozoic metavolcanic rocks from the southern Ashanti volcanic belt, Ghana: Petrogenetic and tectonic setting implications," Precambrian Research, vol. 162, no. 3-4, pp. 403-423, 2008.

[20] N. R. Junner, Geology of the Gold Coast and Western Togoland with Revised Geological Map, Gold Coast Geological Survey Bulletin, 1940.

[21] R. Trompette, "La chaîne panafricaine des Dahomeyides et le bassin des volta (bordure SE du craton Ouest-Africain)," Mém. B.R.G.M., 92, pp. 9-62, 1980.

[22] B. Amard and P. Affaton, "Découverte de Chuaria circularis (Acritarche) dans le bassin des Volta (Haute Volta et Bénin, Afrique de l'Ouest). Age protérozoïque terminal de la formation de la Pendjari et de la tillite sous-jacente," Comptes Rendus-Academie des Sciences II, vol. 299, no. 14, pp. 975980, 1984.

[23] B. Amard, "Chuaria pendjariensis n. sp., acritarche du bassin des Volta, Bénin et Burkina-Faso, Afrique de l'Ouest : un taxon nouveau du Cambrien inférieur," Comptes Rendus_-Academie des Sciences II, vol. 324, no. 6, pp. 477-483, 1997.

[24] P. Affaton, L. Aguirre, and R.-P. Ménot, "Thermal and geodynamic setting of the Buem volcanic rocks near Tiélé, Northwest Bénin, West Africa," Precambrian Research, vol. 82, no. 3-4, pp. 191-209, 1997.

[25] M. Deynoux, P. Affaton, R. Trompette, and M. Villeneuve, "Pan-African tectonic evolution and glacial events registered in Neoproterozoic to Cambrian cratonic and foreland basins of West Africa," Journal of African Earth Sciences, vol. 46, no. 5, pp. 397-426, 2006.

[26] N. Simpara, J. Sougy, and R. Trompette, "Lithostratigraphie et structure du Buem unité externe de la chaine panafricaine des Dahomeyides dans la region de Bassar (Togo)," Journal of African Earth Sciences, vol. 3, no. 4, pp. 479-486, 1985.

[27] M. Caen-Vachette, K. J. M. Pinto, and M. Roques, "Plutons éburnéens et métamorphisme dans le socle cristallin de la chaîne panafricaine au Togo et au Bénin," Revue de Geographie Physique et de Geologie Dynamique, vol. 21, no. 5, p. 351, 1979.

[28] K. Attoh, R. D. Dallmeyer, and P. Affaton, "Chronology of nappe assembly in the Pan-African Dahomeyide orogen, West Africa: evidence from ${ }^{40} \mathrm{Ar} /{ }^{39} \mathrm{Ar}$ mineral ages," Precambrian Research, vol. 82, no. 1-2, pp. 153-171, 1997.

[29] Y. Agbossoumondé, R.-P. Ménot, J.-L. Paquette, S. Guillot, S. Yéssoufou, and C. Perrache, "Petrological and geochronological constraints on the origin of the Palimé-Amlamé granitoids (South Togo, West Africa): a segment of the West African craton paleoproterozoic margin reactivated during the PanAfrican collision," Gondwana Research, vol. 12, no. 4, pp. 476488, 2007.

[30] K. Attoh, "Dahomeyides in Southern Ghana: evidence for oceanic closure and crustal imbrication in a Pan-Africa," Mern. C.I.F.E.G. vol. 22, pp. 159-164, 1990.

[31] M. S. Tairou, P. Affaton, B. E. Sabi, and K. F. Seddoh, “Tectonometamorphic evolution of the Mo and Kara-Niamtougou Orthogneissic Suites, Northern Togo," Global Journal of Geological Sciences, vol. 7, no. 2, pp. 93-100, 2009.

[32] M. El-Hadj Tidjani, P. Affaton, P. Louis, and A. Socohou, "Gravity characteristics of the Pan-African Orogen in Ghana, Togo and Benin (West Africa)," Journal of African Earth Sciences, vol. 7, no. 24, pp. 241-258, 1997.

[33] Y. Agbossoumonde, R.-P. Menot, and S. Guillot, "Metamorphic evolution of Neoproterozoic eclogites from south Togo (West Africa)," Journal of African Earth Sciences, vol. 33, no. 2, pp. 227-244, 2001.
[34] K. Attoh and J. Morgan, "Geochemistry of high-pressure granulites from the Pan-African Dahomeyide orogen, West Africa: constraints on the origin and composition of the lower crust," Journal of African Earth Sciences, vol. 39, no. 3-5, pp. 201-208, 2004.

[35] Y. Agbossoumonde, Les complexes ultrabasiques de la chaîne panafricaine au Togo (Axe Agou-Atakpamé, Sud-Togo). Etude pétrographique, minéralogique et géochimique [Ph.D. thesis], Université Jean Monnet, St. Etienne, France, 1998.

[36] R. P. Ménot, Y. Agbossoumondé, S. Guillot, and G. Duclaux, "Pan-African subduction-collision event evidenced by high$\mathrm{P}$ coronas in metanorites from the Agou massif (Southern Togo)," Precambrian Research, vol. 135, no. 1-2, pp. 1-21, 2004.

[37] B. E. Sabi, Etude pétrologique et structurale du Massif Kabyè, Nord-Togo [Ph.D. thesis], Université de Lomé, 2007.

[38] K. Attoh and P. M. Nude, "Tectonic significance of carbonatites and ultrahigh-pressure rocks in the Pan-African Dahomeyide suture zone, southeastern Ghana," in The Boundaries of the West African Craton, N. Ennih, J.-P. Liégeois et al., Eds., vol. 297 of Special Publications, pp. 217-231, Geological Society, London, UK, 2008.

[39] M. G. Abdelsalam, J.-P. Liégeois, and R. J. Stern, “The saharan metacraton," Journal of African Earth Sciences, vol. 34, no. 3-4, pp. 119-136, 2002.

[40] M. Caen-Vachette, "Age pan-africain des granites de Sinendé, Save et Fita (Dahomey)," Comptes Rendus de l'Académie des Sciences, pp. 1793-1795, 1975.

[41] P. Affaton, A. Kröner, and K. F. Seddoh, "Pan-African granulite formation in the Kabye Massif of Northern Togo (West Africa): $\mathrm{Pb}-\mathrm{Pb}$ zircon ages," International Journal of Earth Sciences, vol. 88, no. 4, pp. 778-790, 2000.

[42] J. P. Petit, "Criteria for the sense of movement on fault surfaces in brittle rocks," Journal of Structural Geology, vol. 9, no. 5-6, pp. 597-608, 1987.

[43] F. Bergerat, Déformations cassantes et champs de contrainte tertiaires dans la plate-forme européenne [Ph.D. thesis], University Pierre and Marie Curie, Paris, France, 1985.

[44] J. Angelier, “Tectonique cassante et néotectonique," Annales de la Société Géologique de Belgique, vol. 112, no. 2, pp. 283-307, 1990.

[45] M. O. Aïte, Analyse de la microfracturation et paléo-contraintes dans le Néocène post-nappes de Grande Kabylie (Algérie) [Ph.D. thesis], Université du Maine, 1994.

[46] C. Castaing, C. Triboulet, J. L. Feybesse, and P. Chevremont, "Tectonometamorphic evolution of Ghana, Togo and Benin in the light of the Pan-African/Brasiliano orogeny," Tectonophysics, vol. 218, no. 4, pp. 323-342, 1993.

[47] U. Wenmenga, M. Kecir, and P. Affaton, "Distribution des filons de dolérite d'après les interprétations géologiques de données aéromagnétiques et leur signification géodynamique (Burkina Faso, Craton ouest africain)," Bulletin du Service Géologique National, vol. 20, no. 2, pp. 254-261, 2009.

[48] M. Popoff, "Du Gondwana à l'atlantique sud: les connexions du fossé de la bénoué avec les bassins du Nord-Est brésilien jusqu'à l'ouverture du golfe de Guinée au crétacé inférieur," Journal of African Earth Sciences, vol. 7, no. 2, pp. 409-431, 1988.

[49] M. K. Mensah, "On the question of the age of Sekondi Series Upper Devonian or Lower Carboniferous rocks of Ghana," Ghana Journal of Science, vol. 2, no. 33, pp. 134-139, 1973.

[50] J. P. Sylvain, J. Collart, A. Aregba, and S. Godonou, "Notice explicative de la carte géologique 1/500.0000è du Togo," Mém. 6, D.G.M.G./B.N.R.M., Lomé-Togo, 120p, 1986. 
[51] Y. D. Da Costa, Biostratigraphie et paléogéographie du basin sédimentaire côtier du Togo [Ph.D. thesis], Université de Lomé, Togo, 2005.

[52] A. A. Antobreh, J. I. Faleide, F. Tsikalas, and S. Planke, "Riftshear architecture and tectonic development of the Ghana margin deduced from multichannel seismic reflection and potential field data," Marine and Petroleum Geology, vol. 26, no. 3, pp. 345-368, 2009. 

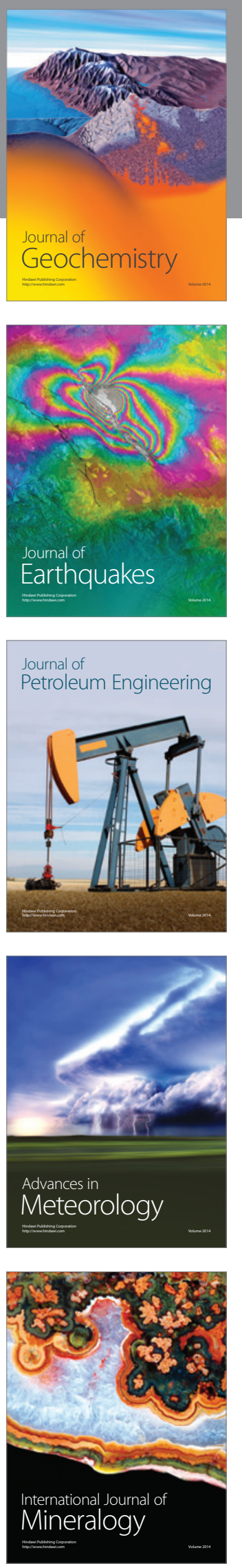
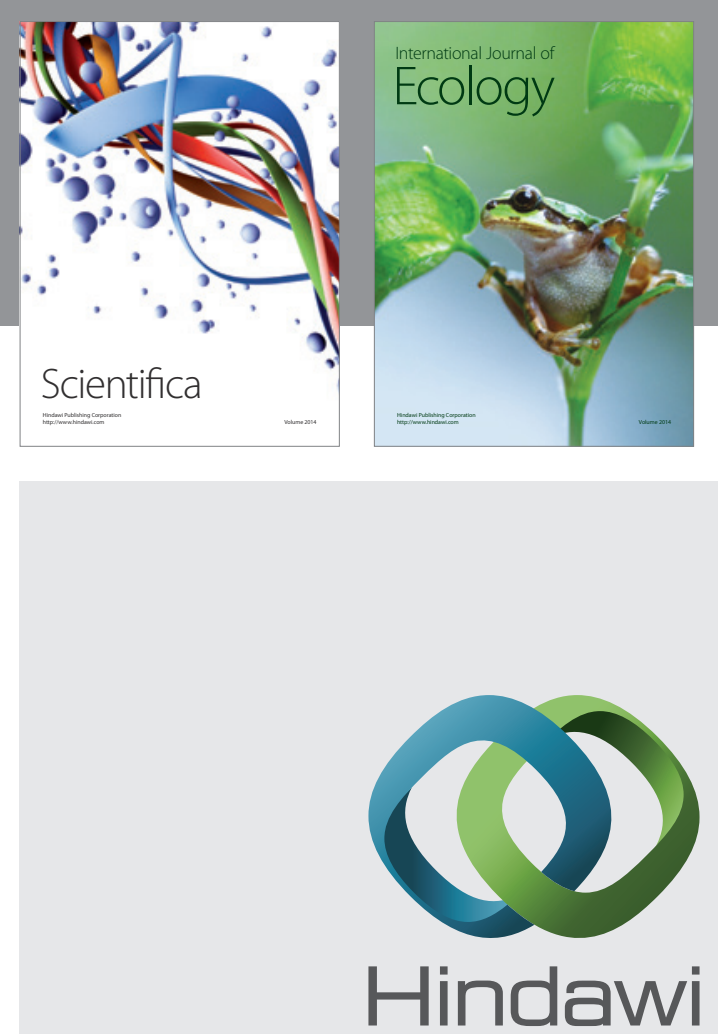

Submit your manuscripts at http://www.hindawi.com
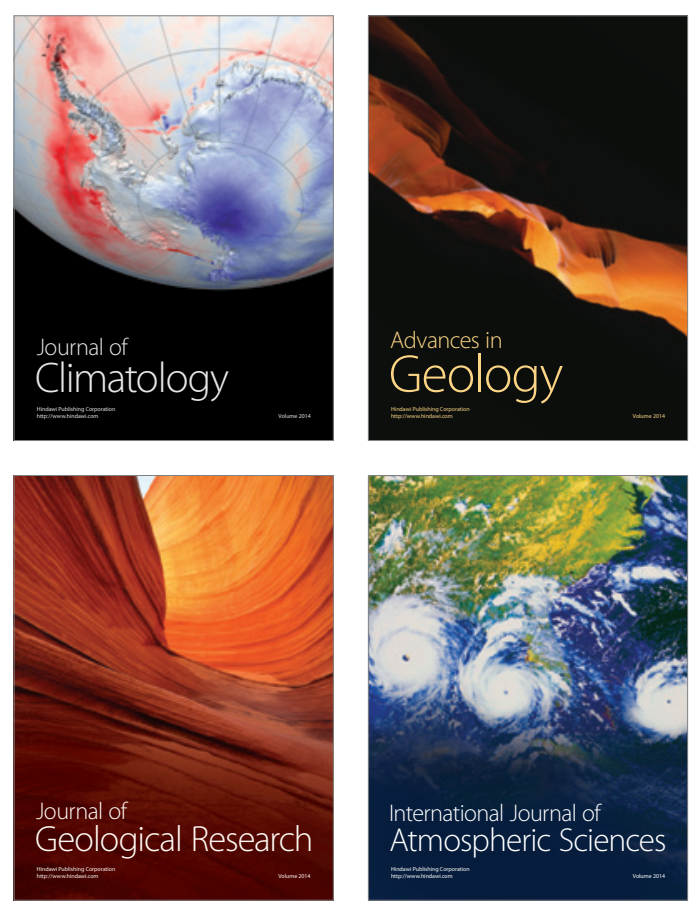
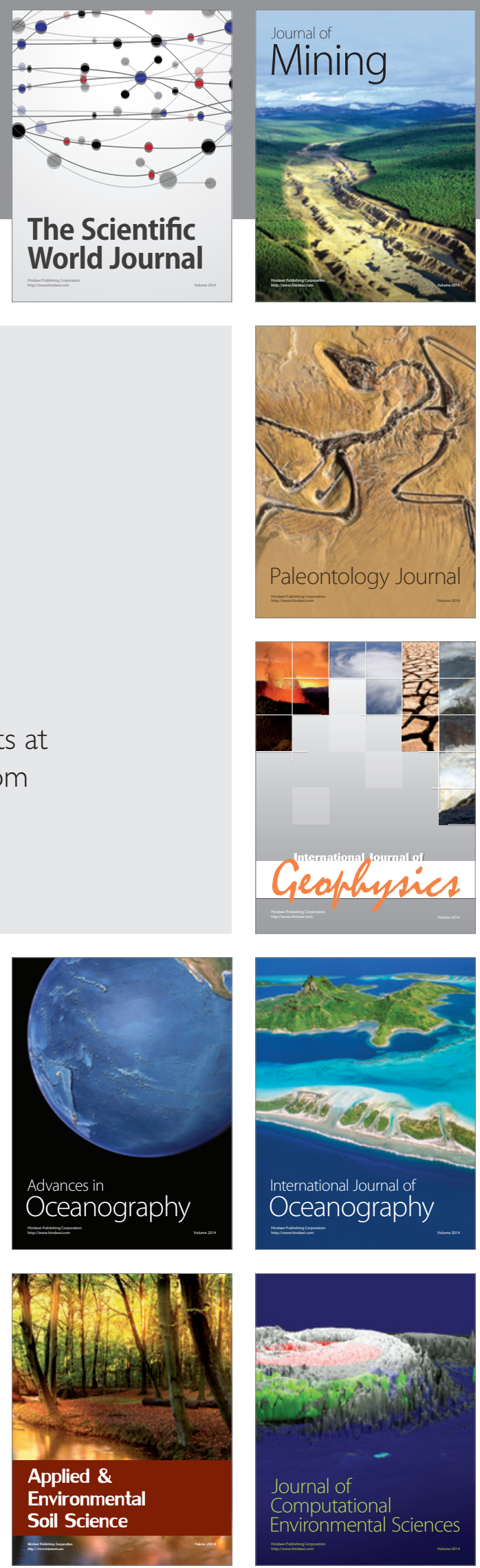